\title{
Studi Pendirian Pabrik Dimetil Karbonat di
}

\section{Blok Tangguh}

\author{
Fajar Premana Putra, Rizky Renanda Nofa, Kuswandi, Gede Wibawa \\ Jurusan Teknik Kimia, Fakultas Teknologi Industri, Institut Teknologi Sepuluh Nopember (ITS) \\ Jl. Arief Rahman Hakim, Surabaya 60111 Indonesia \\ e-mail: gwibawa@chem-eng.its.ac.id
}

\begin{abstract}
Abstrak-Sejak adanya revolusi industry emisi dari gas $\mathrm{CO}_{2}$ semakin meningkat dari tahun ke tahun. Dampak dari peningkatan emisi $\mathrm{CO}_{2}$ adalah global warming yang menyebabkan suhu bumi yang semakin meningkat. Terjadinya global warming juga menyebabkan berbagai bencana dan perubahan iklim. Bahan bakar cair seperti gasoline adalah jenis bahan bakar yang paling banyak digunakan dalam bidang transportasi. Salah satu upaya yang dapat dilakukan untuk meminimalisir emisi $\mathrm{CO}_{2}$ dari kendaraan serta mengurangi penggunaan bahan bakar fosil ialah dengan penambahan zat aditif yang memiliki kandungan oksingen tinggi (oxygenated compound) pada bahan bakar cair seperti gasoline. DMC (Dimethyl Carbonate) merupakan salah satu zat aditif yang dianggap mampu untuk menggantikan zat aditif karena DMC lebih ramah lingkungan dibandingkan dengan zat aditif lainnya karena dapat mengurangi emisi hidrokarbon, $\mathrm{CO}$, NOx dan partikel lainya. DMC juga memiliki kadar oksigen yang relatif tinggi $(53,3$ wt. $\%)$, tekanan uap rendah, nilai oktan campuran yang tinggi.Indonesia sendiri belum memiliki plant untuk menghasilkan DMC. Sehingga untuk dijadikan zat aditif maka produksi DMC dalam negeri harus ditingkatkan terlebih dahulu. Secara garis besar Pabrik DMC terdiri dari Purifikasi Gas Bumi, Sintesa Metanol, Purifikasi Metanol, Sintesa DMC, Purifikasi DMC. Dari studi yang dilakukan untuk Pabrik DMC dengan kapasitas 132,2 MMSCFD Gas Bumi masuk dibutuhkan investasi sebesar MUSD 369,1. Dari analisa ekonomi diperoleh: Internal Rate of Return : 26,49\%; POT: 4,1 tahun; BEP : $67,8 \%$; dan NPV 10 year : MUSD 928,8. Dari keempat parameter sensitifitas yaitu fluktuasi biaya investasi, harga bahan baku, kapasitas, dan harga jual dari produk, terlihat bahwa keempatnya tidak memberikan pengaruh cukup signifikan terhadap kenaikan atau penurunan nilai IRR kilang. Sehingga Pabrik Dimetil Karbonat ini layak untuk didirikan.
\end{abstract}

Kata Kunci- Gas Bumi, Dimetil Karbonat, Desain Pabrik, Zat Aditif.

\section{PENDAhUluan}

$\mathrm{E}^{\mathrm{s}}$ misi dari gas $\mathrm{CO}_{2}$ semakin meningkat dari tahun ke tahun dan dampak dari revolusi industri itu semakin dirasakan saat ini. Dampak dari peningkatan emisi $\mathrm{CO}_{2}$ adalah terjadinya global warming yang menyebabkan suhu bumi yang semakin meningkat. Terjadinya global warming juga menyebabkan berbagai bencana dan perubahan iklim di seluruh belahan bumi. Sehingga global warming harus segera ditanggulangi.

Seiring dengan berkembangnya dunia industri dan otomotif, peningkatan emisi $\mathrm{CO}_{2}$ ini semakin tidak dapat terbendung. Penggunaan bahan bakar minyak berbasis energi foseil secara terus menerus sebagai sumber energi utama dunia juga signifikan di atmosfer dan memberikan efek pemanasan global. Pembakaran dari bahan bakar fosil memberikan kontribusi sebesar $73 \%$ terhadap produksi $\mathrm{CO}_{2}$. Sehingga perhatian dunia terhadap permasalahan pemanasan global difokuskan sebagai tindakan dalam mencari solusi terhadap emisi greenhouse gas (GHS).

Bahan bakar cair seperti gasoline adalah jenis bahan bakar yang paling banyak digunakan dalam bidang transportasi. Salah satu upaya yang dapat dilakukan untuk meminimalisir emisi $\mathrm{CO}_{2}$ dari kendaraan serta mengurangi penggunaan bahan bakar fosil ialah dengan penambahan zat aditif yang memiliki kandungan oksingen tinggi (oxygenated compound) pada bahan bakar cair seperti gasoline. Oxygenated compound merupakan salah satu senyawa organik yang dapat digunakan sebagai zat aditif. Selain dapat digunakan untuk mengurangi emisi, oxygenated compound juga dapat digunakan untuk meningkatkan nilai oktan bahan bakar. Oxygenated compound meliputi senyawa alkohol dan eter.

DMC (Dimethyl Carbonate) merupakan salah satu zat aditif alternatif yang dianggap mampu untuk menggantikan zat aditif konvensional, karena DMC lebih ramah lingkungan dibandingkan dengan zat aditif lainnya dan dapat mengurangi emisi hidrokarbon, $\mathrm{CO}$, NOx dan partikel lainya. DMC juga memiliki kadar oksigen yang relatif tinggi (53,3 wt.\%), tekanan uap rendah, nilai oktan campuran yang tinggi,. Selain berpotensi untuk menjadi zat aditif bagi bahan bakar, DMC memiliki memiliki berbagai macam kegunaan lain, yaitu : pelarut untuk berbagai macam aplikasi mulai dari cat hingga zat adhesive, produk intermediate untuk berbagai sintesa bahan organik, dan juga dapat digunakan sebagai bahan baku dari pembuatan biodiesel. Indonesia sendiri belum memiliki plant untuk menghasilkan DMC. Sehingga untuk dijadikan zat aditif maka produksi DMC dalam negeri harus ditingkatkan terlebih dahulu dengan cara mendirikan suatu plant penghasil DMC yang bersifat ramah lingkungan untuk mengatasi berbagai permasalahan yang menyangkut bahan bakar di Indonesia.

\section{URAIAN PROSES}

\section{A. Unit Desulfurisasi}

Studi pendirian pabrik Dimetil Karbonat ini mengambil feed dari gas alam dari Kabupaten Teluk Bintuni, Papua Barat.

Bahan baku gas alam yang digunakan memiliki kandungan $\mathrm{H}_{2} \mathrm{~S}$ sebanyak 2,3\%. sulfur tersebut harus dihilangkan karena dapat meracuni katalis pada reaktor. Kandungan $\mathrm{H}_{2} \mathrm{~S}$ maksimal yang diperbolehkan masuk ke dalam sistem proses hanyalah 0,2 ppm. Proses proses 
desulfurizer menggunakan antuan adsorben $\mathrm{ZnO}$ dimana adsorben tersebut sangat selektif dalam menghilangkan $\mathrm{H}_{2} \mathrm{~S}$. Reaksi Desulfurisasi yang terjadi adalah sebagai berikut:

$$
\mathrm{ZnO}+\mathrm{H}_{2} \mathrm{~S} \leftrightarrow \mathrm{ZnS}+\mathrm{H}_{2} \mathrm{O}
$$

Feed memasuki unit desulfurizer pada suhu $370{ }^{\circ} \mathrm{C}$ dan tekanan 30 bar. Setelah melalui desulfurizer, diharapkan kandungan sulfur dalam gas alam turun hingga kurang dari 0,2 ppm.

\section{B. Unit Reforming}

Proses selanjutnya adalah proses reforming, yaitu merupakan proses untuk menghasilkan syngas (CO dan $\mathrm{H}_{2}$ ) dari bahan baku gas alam. Terdapat dua macam proses reforning yang digunakan pada pabrik ini, yaitu Steam Reforming dan Autothermal Reforming.

Dalam proses steam reformer, gas alam akan dicampurkan dengan steam yang berasal dari proses utilitas dengan kondisi masukan pada reaktor steam reformer suhu $780{ }^{\circ} \mathrm{C}$ dan tekanan 29 bar. Pada proses ini akan terjadi proses pemecahan metana dan peruraian gas CO. Reaksi yang terjadi pada proses steam reformer adalah sebagai berikut:

$\mathrm{CnHm}+\mathrm{m} \mathrm{H}_{2} \mathrm{O} \leftrightarrow \mathrm{n} \mathrm{CO}+(\mathrm{m} / 2+\mathrm{n}) \mathrm{H}_{2}$

$\mathrm{CO}+\mathrm{H}_{2} \mathrm{O} \leftrightarrow \mathrm{CO}_{2}+\mathrm{H}_{2}$

Aliran keluaran dari steam reformer kemudian akan memasuki proses autothermal reformer untuk mengkonversi gas alam yang belum bereaksi agar dihasilkan syngas yang lebih banyak.

Autothermal reforming merupakan proses yang bertujuan untuk mengkonversi gas alam dan sisa gas alam dari steam reformer menjadi syngas. Autothermal reformer berupa Jacketed Vessel dengan menggunakan katalis berkada nikel tinggi dengan suhu operasi $1025^{\circ} \mathrm{C}$ dan tekanan operasi 27,5 bar. Reaktor jenis ini menggunakan pendingin berupa cooling water yang terus mengalir secara kontinu. Disini juga terjadi penambahan oksigen yang berasal dari oxygen storage pada temperatur $130{ }^{\circ} \mathrm{C}$ dan tekanan 27,5 bar. Reaksi kimia yang terjadi meliputi:

$$
\begin{aligned}
& \mathrm{CnHm}+\mathrm{n} / 2 \mathrm{O}_{2} \leftrightarrow \mathrm{n} \mathrm{CO}+(\mathrm{m} / 2) \mathrm{H}_{2} \\
& \mathrm{CO}+\mathrm{H}_{2} \mathrm{O} \leftrightarrow \mathrm{CO}_{2}+\mathrm{H}_{2} \\
& \mathrm{CnHm}+(\mathrm{n}+\mathrm{m} / 4) \mathrm{H}_{2} \mathrm{O} \leftrightarrow \mathrm{n} \mathrm{CO}+(\mathrm{m} / 2+\mathrm{n}) \mathrm{H}_{2}
\end{aligned}
$$

\section{Unit Sintesa Metanol}

Proses selanjutnya adalah proses sintesa dan pemurnian metanol. Feed dari proses autothermal reformer akan mengalami treatment terlebih dahulu untuk menyesuaikan kondisi operasi reaktor metanol, yaitu suhu operasi $230-270{ }^{\circ} \mathrm{C}$ dengan tekanan operasi 50-100 bar. Setelah terbentuk metanol, maka akan dilakukan proses pemurnian metanol yang terbentuk dengan menggunakan flash separator dan kolom distilasi metanol.

Pada flash separator akan dipisahkan kandungan metanol yang terbentuk dengan syngas yang belum terkonversi. Kondisi operasi pada flash separator adalah suhu $50{ }^{\circ} \mathrm{C}$ dan tekanan 2 bar. Bottom product dari proses ini adalah larutan kaya akan metanol dan air, dan upper product adalah gas yang kaya akan syngas yang akan direcycle kembali.

Raw methanol yang dialirkan ke kolom distilasi masih mengandung air dan gas terlarut yang tidak diinginkan dengan titik didih di bawah titik didih methanol meskipun telah dipisahkan sebelumnya di flash separator, sehingga perlu dimurnikan pada kolom distilasi. Pada kolom distilasi ini digunakan total condenser, dimana gas-gas dengan titik didih di bawah titik didih air, yang salah satunya merupakan metanol, menuju ke atas dan akan melalui proses pengolahan selanjutnya. Sedangkan produk bawah berupa air dan metanol, dengan kandungan metanol $0,25 \%$ berat. Pada kolom ini digunakan total reboiler, dengan produk bawah diambil dari bawah kolom untuk kemudian menuju ke waste water treatment process.

TABel 1. Produk Unit Sintesa Metanol

\begin{tabular}{lc}
\hline \hline Komponen & Fraksi Mol \\
\hline Methanol & 0,98221 \\
$\mathbf{H}_{2} \mathbf{O}$ & 0,017 \\
$\mathbf{C O}$ & $<0,0005$ \\
Methane & $<0,0002$ \\
Hydrogen & $<0,0006$ \\
Nitrogen & $<0,0002$ \\
\hline \hline
\end{tabular}

\section{Unit Sintesa DMC}

Upper product dari kolom distilasi yang kaya akan metanol akan menjadi feed untuk proses sintesa DMC. Reaktor yang dipakai untuk proses sintesa DMC ini adalah trickle bed reaktor, karena pada proses ini terdiri dari 2 fase yang berbeda yaitu fase liquid (metanol dan Butylene Oxide) dan fase gas $\left(\mathrm{CO}_{2}\right)$. Katalis yang digunakan pada reaksi ini adalah Cerium Oxide $\left(\mathrm{CeO}_{2}\right)$. Reaksi kesetimbangan pada proses direct synthesis pada awalnya hanya menghasilkan konversi yang rendah. Karena itu, untuk menambah laju konversi, kesetimbangan harus digeser ke arah produk, yaitu dengan penambahan dehydrating agent Butylene Oxide untuk mengikat $\mathrm{H}_{2} \mathrm{O}$ yang terbentuk sehingga reaksi kesetimbangan bergeser ke arah produk. Reaksi yang terjadi pada reaktor DMC ini adalah sebagai berikut:

$$
\begin{aligned}
& 2 \mathrm{CH}_{3} \mathrm{OH}+\mathrm{CO}_{2} \leftrightarrow \mathrm{C}_{3} \mathrm{H}_{6} \mathrm{O}_{3}+\mathrm{H}_{2} \mathrm{O} \\
& \mathrm{C}_{4} \mathrm{H}_{8} \mathrm{O}+\mathrm{H}_{2} \mathrm{O} \leftrightarrow \mathrm{C}_{4} \mathrm{H}_{10} \mathrm{O}_{2}
\end{aligned}
$$

Kondisi operasi pada reaktor dijaga pada suhu tidak lebih dari $130{ }^{\circ} \mathrm{C}$ dan tekanan 30 bar. Hal ini untuk mencegah terjadinya side product dari reaksi sintesa DMC dan konversi yang tercapai tetap tinggi. Berdasarkan hasil percobaan, didapatkan bahwa konversi dari methanol ke DMC mencapai 92,4\%. Produk yang keluar dari reaktor terdiri dari senyawa DMC, methanol, $\mathrm{CO} 2$, dan Butylene Glycol (tanpa kandungan $\mathrm{H}_{2} \mathrm{O}$ akibat bereaksi dengan Butylene Glycol). Aliran produk kemudian masuk ke unit purifikasi DMC.

Dari reaktor DMC, product akan mengalami pemurnian untuk mencapai tingkat kemurnian sesuai dengan standard yang ditetapkan di pasaran. Produk DMC yang akan dipasarkan memiliki kemurnian 99,8\%. Tahapan proses pemurnian DMC yang dilakukan adalah tahapan pemisahan $\mathrm{CO}_{2}$, pemisahan Butylene Glycol, dan pemisahan DMC dengan methanol, pemurnian distilate stream untuk recycle, penurnian solvent dan dehydrating agent.

TABel 2. Produk Unit SinTESA DMC

\begin{tabular}{lc}
\hline \hline \multicolumn{1}{c}{ Komponen } & Fraksi Mol \\
\hline Dimethyl Carbonate & 0,9964 \\
Butylene Oxide & 0,003 \\
Butylene Glicol & 0,0004 \\
\hline \hline
\end{tabular}




\section{ANALISA EKONOMI}

Dari hasil perhitungan pada neraca ekonomi didapatkan Total Cost Investment pabrik ini sebesar MUSD 369,1 dengan bunga 10,5\% per tahun dan NPV 10 tahun sebesar MUSD 928,8. Selain itu, diperoleh IRR sebesar 26,49\% dan BEP sebesar $67,8 \%$ dimana pengembalian modalnya selama 3.5 tahun. Umur dari pabrik ini diperkirakan selama 10 tahun dengan masa periode pembangunannya selama 2 tahun di mana operasi pabrik ini 330 hari/tahun [21].

\section{KESIMPULAN}

Berdasarkan hasil analisa ekonomi didapatkan nilai IRR sebesar $26,49 \%$ yang lebih tinggi dari suku bunga bank yaitu $10,5 \%$ per tahun, NPV 10 tahun sebesar MUSD 928,8 dimana pengembalian modalnya selama 4,1 tahun maka Pabrik Dimetil Karbonat ini layak untuk didirikan.

\section{DAFTAR PUSTAKA}

[1] Aspen Technology, Inc. "Aspen Physical Property System", Burlington USA.2010.

[2] Brownell, Lloyd E. dan Edwin H. Young, "Process Equipment Design”, John Wiley \& Sons, New York, 1959.

[3] Geankoplis, Christie J.,"Transport Processes and Unit Operations", $3^{\text {rd }}$ edition, $\quad$ Prentice-Hall of India, New Delhi, 1997.

[4] Kern, Donald Q.,"Process Heat Transfer", International Edition, McGraw-HillBook Company, Tokyo, 1965.

[5] Ludwig. E. Ernest "Design For Chemical and Petrochemichal Plants".,Gull Publishing Houston-Texas, 1947.

[6] Moss, Dennis, “Pressure Vessel Design Manual”, Elsevier: Great Britain, 2013.
[7] Peters, Max S., Klaus D. Timmerhaus, dan Ronald E. West "Plant Design and Economics for Chemical Engineers", $5^{\text {th }}$ edition, McGraw-Hill Book Company, Boston, 2003.

[8] Silla,H., "Chemical Process Engineering Design and Economics”, Stevens Institute of Technology, New Jersey USA, 2003.

[9] Smith, Robin.,"Chemical Process Design",McGraw Hill International Book Company, Singapore, 1955.

[10] Ulrich, Gael D.,"A Guide to Chemical Engineering Process Design and Economic”, John Wiley \& Sons, Canada, 1984.

[11] Van Ness, Smith, "Introduction to Chemical Engineering Thermodynamics", $4^{\text {th }}$ edition, International edition, McGraw Hill Inc, Singapore, 1967.

[12] Van Winkle, Matthew.,"Distillation", McGraw Hill Book Company, New York, 1967.

[13] SK Ditjen Migas No. 26525.K/10/DJM.T/2009

[14] UU No.36 Tahun 2008

[15] Chemical Engineering Magazine

[16] http://tubankab.bps.go.id

[17] http:// www.matche.com

[18] http:// www.esdm.go.id

[19] http://www.bi.go.id

[20] http:// www.wikipedia.org

[21] Himmelblau, David M. 1989. Basic Principles and Calculation in Chemical Engineering. 5th edition. Prentice Hall International Inc. : Singapore.

[22] Peters, Max S. and Timmerhauss, Klaus D. 1991. Plant Design and Economics For Chemical Engineerings. 4th edition. McGraw Hill Book Co : Singapore. 